\title{
Measuring climate change vulnerability: a comparison of two indexes
}

\begin{abstract}
A.A. Urothody ${ }^{1}$ and H.O. Larsen ${ }^{2}$
Climate change is predicted and currently observed to especially affect the rural poor, and some sort of support for adaptation is relevant. This paper tests two vulnerability assessment indexes in Lete and Kunjo VDCs in Mustang District: the Livelihood Vulnerability Index (LVI) and the Livelihood Effect Index (LEI). The indexes are completed based on primary data from 60 randomly selected respondents and the vulnerabilities at VDC and household levels are assessed. The figures resulting from the vulnerability assessments correspond with contextual information from the area elicited during key informant interviews and the methods are concluded useful in a Nepalese context. Both indexes validly reflect the relative differences between the two VDCs in terms of vulnerability to climate change impacts and factors contributing to it and both could therefore usefully form the basis for a nationally applicable index to identify and prioritise mitigation needs. However, a number of challenges to using indexes and basing them on respondents perceptions are recognised.
\end{abstract}

Key words: Climate change, livelihoods, Mustang, vulnerability

$\mathbf{T}$ he scientific community by now agrees that climate change is real, it will become worse, and the already poor and vulnerable will be affected the most (IPCC, 2007). Based on temperature observations in Nepal from 1977-1994, a warming trend increasing with altitude is concluded (Shrestha et al., 1999) and an increase in the frequency of high intensity rainfall, leading to more flash floods and landslides, has been reported (Chalise and Khanal, 2001 and ICIMOD, 2007). There is also evidence of more intense precipitation events and an increase in the number of flood days in some rivers while other rivers show reduction in flows in the dry season, with implications for both water supply and energy generation (Shakya, 2003). Significant and consistent increases in temperatures and annual precipitation rates are predicted for Nepal in the years 2030, 2050 and 2100 across various climate models (Agrawala et al., 2003).

Most of the Nepalese population is engaged within agricultural systems that typically involve extraction of forest products (Pokharel and Byrne, 2009), and $31 \%$ of the population survive below the poverty line (ADB, 2008). It is therefore feared that climate change will undermine the national development progress with most severe consequences for the poor who typically depend on climate-sensitive natural resources (MoEST and UNDP 2008). The capacity and scale of adaptation to climate change depends on the vulnerability of people and natural systems to the impacts, where vulnerability is susceptibility shaped by exposure, sensitivity and resilience (Kasperson et al. 1996). In relation to climate change, vulnerability relates to direct effects such as more storms, floods, hot weather, lower/higher rainfall or sea level rises that lead to indirect effects such as lower productivity from changing ecosystems or disruption to economic systems. With the poor being more directly dependent on ecosystem services and products for their livelihoods, the vulnerability of natural systems has profound implications (IISD, 2003).

Vulnerability is defined by the IPCC (2001) as a function of exposure, sensitivity and adaptive capacity. Exposure is the magnitude and duration of the climate-related exposure such as a warmer climate, drought, change in precipitation or natural hazards, sensitivity is the degree to which the system is affected by the exposure, and adaptive capacity is the system's ability to withstand or recover from the exposure (Ebi et al., 2006). Human adaptation remains an insufficiently studied part of the subject of climate change (Brooks and Adger, 2003). Emerging evidence indicates that adaptation and coping strategies by the poor in developing countries are highly varied and

\footnotetext{
1 College of Forestry, Kerala Agricultural University, Kerala, India, Pin- 680 656, Email: ashiquealiu@gmail.com

2 ComForM project, Institute of Forestry, Trubhuwan University, and Forest \& Landscape, University of Copenhagen,

Email: hol@life.ku.dk
} 
local-level studies are needed for development policies to be effective (Smit et al. 2007). In Nepal, a few studies have indicated that people do experience increased temperatures and changed rainfall patterns (e.g. Chapagain et al. 2009; Regmi et al. 2009), and that adaptive capacities of poor and marginalised households, and especially women, are low (Oxfam 2009). Vulnerability assessments are useful when, for example, deciding what regions or villages to target for with development programmes.

This paper seeks to assess vulnerability induced by climate change in two rural communities in lower Mustang District of Nepal through application of two different indices, one proposed by Hahn et al. (2009): the Livelihood Vulnerability Index (LVI) and one based on the DFID (1999) sustainable livelihood framework approach: the Livelihood Effect Index (LEI). Both the LVI and the LEI provide a community based composite index, while the LEI also provides a household based composite index.

\section{Materials and methods}

\section{Study area}

The study was conducted in Lete and Kunjo Village Development Committees (VDCs) in lower Mustang. The altitude ranges from 2200 to $3000 \mathrm{~m}$, the average annual precipitation is $1242 \mathrm{~mm}(1978-2007)$ and the rainfall peaks in June to September. The yearly average temperature is $12.3{ }^{\circ} \mathrm{C}(1978-2007)$ (Department of Hydrology and Meteorology, 2008). The area is under the jurisdiction of Annapurna Conservation Area Project (ACAP). There are 174 and 189 households in Lete and Kunjo VDCs respectively, and total populations of 668 and 1019 (NPC, 2001). Agriculture and tourism are the major livelihood options in the area. Rice, wheat, maize, barley, buckwheat, and potato are the major crops in the area. Livestock herding is another important agricultural activity. The area is surrounded by alpine coniferous forests and many people depend on forest resources for their livelihood, in addition to labour migration. Lete village is located on a major trekking and transport trail connecting lower lying parts of Nepal with the Tibetan border. More than twenty major tourist hotels operate in Lete, serving approximately 26,000 over-night visitors in 2006 (Christensen, et al., 2009).

\section{Primary data collection}

Primary data for calculating the LVI and LEI according to formulas presented below were collected using key informant interviews and a structured household questionnaire. Data for the LVI were collected using indicators provided by Hahn et al., (2009) and Eriksen and Kelly (2006) (Table 1). Key informant interviews yielded contextual information and were used to identify locally relevant indicators of climate change impacts from a list compiled from Hahn et al. (2009), Lohani (2007), Razafindrabe (2007), Eriksen and Kelly (2006), Selvaraju et al. (2006), Dahal (2006) and Agrawala et al. (2003). The indicators selected were used to develop the LEI (Table 2). The questionnaire developed to yield information for both the LVI and the LEI was administered to a total of 60 randomly selected households in the two VDCs. Key informant interviews also provided contextual information for verifying the outcome of the vulnerability assessments.

\section{The Livelihood Vulnerability Index (LVI)}

The LVI developed by Hahn et al. (2009) is comprised of seven major components: (i) socio-demographic profile, (ii) livelihood strategies, (iii) social networks, (iv) health, (v) food, (vi) water, and (vii) natural disasters and climate variability. For each component relevant sub-components were identified during key informant interviews as described above (Table 1). The LVI components reflect the IPCC (2001) contributing factors to vulnerability: adaptive capacity is covered by components (i)-(iii), sensitivity by (iv)(vi), and exposure by (vii).

The LVI constructs a balanced weighted average where each sub-component contributes equally to the overall index. Each of the sub-components is measured on a different scale, they are therefore first standardised as an index using equation 1 (Hahn et al. 2009):

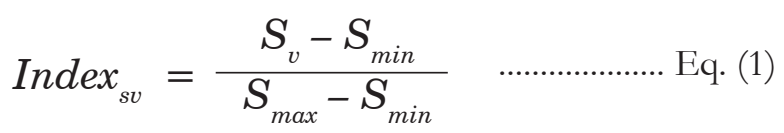

$\mathrm{S}_{\mathrm{v}}: \quad$ the original subcomponent or indicator value for $\mathrm{VDC}_{\mathrm{v}}, \mathrm{v}=1,2$.

$\mathrm{S}_{\max }$ and $\mathrm{S}_{\min }$ : the maximum and minimum subcomponent values determined using all the subcomponent values from both the VDCs.

After standardisation the value of each major component is calculated using equation 2 :

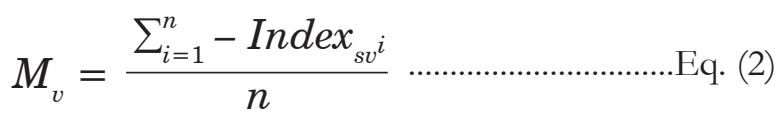


$\mathrm{M}_{\mathrm{v}}: \quad$ one of the seven major components for $\quad C_{v}=\frac{\sum_{i=1}^{n} l_{i}}{n}$ VDC.

Index ${ }_{\text {svi }}$ the sub-component value of indicator $i$ belonging to major component $\mathrm{M}_{v}$ in VDC .

$\mathrm{n}$ : the number of sub-components in each major component, $\mathrm{n}=1-5$.

The LVI is scaled from 0 (least vulnerable) to 1 (most vulnerable). The VDC-level LVI is calculated as the weighted average of the seven major components

$L V I_{v}=\frac{\sum_{i=1}^{7}-W_{M i} M_{v i}}{\sum_{i=1}^{7}-W_{M i}}$

using equation 3 :

LVI: the Livelihood Vulnerability Index for VDC.

$\mathrm{M}_{\mathrm{vi}}$ : the value of the $\mathrm{i}^{\text {th }}$ major component in $\mathrm{VDC}_{\mathrm{v}}$, $\mathrm{i}=1-7$.

$\mathrm{W}_{\mathrm{Mi}}$ : the weight of major component $\mathrm{i}$, decided by the number of sub-components in the major component.

\section{The Livelihood Effect Index (LEI)}

The DFID (1999) sustainable livelihood framework approach is used for calculating the LEI for each of Lete and Kunjo VDCs and for different wealth groups as defined by a participatory wealth ranking (better off, medium, poor and very poor). Percentage values (for each VDC and livelihood group) of each effect indicator obtained from the household questionnaire were first standardised using equation 1 (minimum: 0, maximum: 100) and then used to calculate the index values for each capital (natural, human, social, physical and financial) using equation 4 :
$\mathrm{C}_{\mathrm{v}}$ : the value for each household capital for $\mathrm{VDC}_{\mathrm{v}}$, $\mathrm{v}=1,2$.

$\mathrm{I}_{\mathrm{i}}$ : the effect indicator value for capital $\mathrm{i}, \mathrm{i}=1-5$.

$n$ : the number of indicators forming the capital.

The LEI is scaled from 0 (least effected) to 1 (most effected). The VDC-level LEI is calculated as the weighted average of all capitals using equation 5 :

$L E I_{v}=\frac{\sum_{i=1}^{5}-W_{i} C_{v i}}{\sum W_{i}}$ Eq. (5)

LEI : the Livelihood Effect Index for VDC.

$\mathrm{C}_{\mathrm{vi}}:$ the value of capital i for VDC .

$\mathrm{W}_{\mathrm{i}}$ : the weight of each capital, decided by the number of indicators in the capital.

LEI values for the different wealth groups were calculated as for VDCs.

\section{Results and discussion}

LVI values are presented for the VDCs of Lete and Kunjo separately in Table 1. The LVI of Lete VDC is lower than for Kunjo due to its slightly higher adaptive capacity and lower levels of sensitivity and exposure. Looking at the sub-components, the higher vulnerability of Kunjo is caused especially by low levels of diversification, water problems and the presence of female headed households. 
Table 1 : Indexed sub-components, major components, and overall Livelihood Vulnerability Index (LVI) ${ }^{1}$ for Lete and Kunjo VDCs, Mustang ${ }^{2}$ in 2009.

\begin{tabular}{|c|c|c|c|c|c|}
\hline Sub-components & Lete & Kunjo & Major components & Lete & Kunjo \\
\hline Dependency ratio & 0.238 & 0.229 & Socio demographic profile & 0.268 & 0.224 \\
\hline Percent of female-headed households & 0.167 & 0.367 & & & \\
\hline $\begin{array}{l}\text { Percent of households where head of household has not } \\
\text { attended school }\end{array}$ & 0.500 & 0.267 & & & \\
\hline Percent of households with orphans & 0.167 & 0.033 & & & \\
\hline $\begin{array}{l}\text { Percent of households with family member working in a } \\
\text { different community }\end{array}$ & 0.667 & 0.433 & Livelihood strategies & 0.365 & 0.359 \\
\hline $\begin{array}{l}\text { Percent of households dependent solely on agriculture as } \\
\text { income source }\end{array}$ & 0.100 & 0.233 & & & \\
\hline Average agricultural Livelihood Diversification Index & 0.330 & 0.410 & & & \\
\hline $\begin{array}{l}\text { Percentage household had to receive help through social } \\
\text { networks }\end{array}$ & 0.333 & 0.200 & Social networks & 0.400 & 0.400 \\
\hline $\begin{array}{l}\text { Percentage household borrowed money through social } \\
\text { networks }\end{array}$ & 0.300 & 0.267 & & & \\
\hline $\begin{array}{l}\text { Percent of households that have not gone to their local } \\
\text { government for assistance for the past } 12 \text { months }\end{array}$ & 0.567 & 0.733 & & & \\
\hline Average time to health facility & 0.590 & 0.286 & Health & 0.297 & 0.162 \\
\hline Percent of households with family member with chronic illness & 0.200 & 0.133 & & & \\
\hline $\begin{array}{l}\text { Percentage of household with members missed school/work in } \\
\text { past two weeks due to illness }\end{array}$ & 0.100 & 0.067 & & & \\
\hline $\begin{array}{l}\text { Percent of households dependent solely on family farm for } \\
\text { food }\end{array}$ & 0.100 & 0.067 & Food & 0.206 & 0.292 \\
\hline $\begin{array}{l}\text { Percentage of household struggle to find food to support whole } \\
\text { year }\end{array}$ & 0.367 & 0.367 & & & \\
\hline Average Crop Diversity Index & 0.398 & 0.727 & & & \\
\hline Percent of households that do not save crops & 0.100 & 0.300 & & & \\
\hline Percent of households that do not save seeds & 0.067 & 0.000 & & & \\
\hline $\begin{array}{l}\text { Percentage of household reported to have water availability } \\
\text { problem }\end{array}$ & 0.233 & 0.667 & Water & 0.210 & 0.467 \\
\hline Percent of households that utilize a natural water source & 0.187 & 0.267 & & & \\
\hline $\begin{array}{l}\text { Average number of flood, drought, and landslides etc. events in } \\
\text { the past } 6 \text { years }\end{array}$ & 0.533 & 0.652 & $\begin{array}{l}\text { Natural disasters and } \\
\text { climate variability }\end{array}$ & 0.489 & 0.520 \\
\hline $\begin{array}{l}\text { Percent of households that did not receive a warning about } \\
\text { recent natural disasters }\end{array}$ & 1.000 & 1.000 & & & \\
\hline $\begin{array}{l}\text { Percent of households with an injury or death as a result of } \\
\text { natural disasters }\end{array}$ & 0.133 & 0.200 & & & \\
\hline $\begin{array}{l}\text { Mean standard deviation of monthly average of average } \\
\text { maximum daily temperature (2001-2007) }\end{array}$ & 0.379 & 0.379 & & & \\
\hline $\begin{array}{l}\text { Mean standard deviation of monthly average of average } \\
\text { minimum daily temperature (2001-2007) }\end{array}$ & 0.401 & 0.401 & & & \\
\hline $\begin{array}{l}\text { Mean standard deviation of monthly average precipitation } \\
(2001-2007)\end{array}$ & 0.486 & 0.486 & & & \\
\hline
\end{tabular}
(2001-2007)

$\begin{array}{ll}\text { LVI-Lete } & 0.332 \\ \text { LVI-Kunjo } & 0.353\end{array}$

${ }^{1}$ Following Hahn et al. (2009). Sub-components are based on Hahn et al. (2009) and Eriksen and Kelly (2006).

${ }^{2}$ Data were obtained from Key informants and a household questionnaire administered to 60 randomly selected households.

LEI values show higher effects of climate change on households in Kunjo VDC compared to Lete (Table 2). This is primarily a result of higher effects on physical capital, where Kunjo was hit by a landslide that destroyed houses. Also effects of climate change on fire, reduced access to roads, and the availability of aid were important. In Lete VDC, on the other hand, natural water sources were being depleted and a relatively high level of outmigration was taking place. 
Table 2 : Climate change effect indicator values, household capital indexes and overall Livelihood Effect Index (LEI) for Lete and Kunjo VDCs, Mustang in 2009. $\mathrm{N}=60$.

\begin{tabular}{|c|c|c|c|c|c|}
\hline Indicators & Lete & Kunjo & $\begin{array}{l}\text { Household } \\
\text { capitals }\end{array}$ & Lete & Kunjo \\
\hline Percentage of household having reductions in nutrition & 83.0 & 90.0 & Human capital & 0.493 & .513 \\
\hline Percentage of household having mental and/or physical stress & 86.7 & 90.0 & & & \\
\hline Percentage of household having loss of human life, injury or new diseases & 20.0 & 13.3 & & & \\
\hline $\begin{array}{l}\text { Percentage of household having public safety problems from forest/wild } \\
\text { fire }\end{array}$ & 26.7 & 43.3 & & & \\
\hline Percentage of household experienced out-migration of skilled members & 30.0 & 20.0 & & & \\
\hline Percentage of household reported their natural resource base reduced & 80.0 & 83.3 & Natural capital & 0.827 & 0.773 \\
\hline Percentage of household having crop losses or reduction in crop production & 93.3 & 93.3 & & & \\
\hline $\begin{array}{l}\text { Percentage of household having new insect/weed infestation and/or crop } \\
\text { diseases }\end{array}$ & 96.7 & 100.0 & & & \\
\hline Percentage of household reported loss from dairy and livestock production & 77.6 & 85.8 & & & \\
\hline Percentage of household reported their natural water source is depleting & 65.8 & 24.2 & & & \\
\hline Percentage of household having losses to housing or property & 0.0 & 20.0 & Physical capital & 0.050 & 0.283 \\
\hline $\begin{array}{l}\text { Percentage of household reported reduced access and use of roads and } \\
\text { transport facilities }\end{array}$ & 10.0 & 36.7 & & & \\
\hline Percentage of household reported to have some sort of financial crisis & 20.0 & 13.3 & $\begin{array}{l}\text { Financial } \\
\text { capital }\end{array}$ & 0.233 & 0.233 \\
\hline $\begin{array}{l}\text { Percentage of household reported to have unemployment from } \\
\text { drought/natural hazard-related production declines }\end{array}$ & 20.0 & 20.0 & & & \\
\hline $\begin{array}{l}\text { Percentage of household reported to have some sort of losses from tourism } \\
\text { industry }\end{array}$ & 30.0 & 36.7 & & & \\
\hline $\begin{array}{l}\text { Percentage of household received helps from their social networks (eg: } \\
\text { friends, community, eco-clubs, NGO) to cope up with climate change }\end{array}$ & 46.7 & 36.7 & Social capital & 0.300 & 0.350 \\
\hline $\begin{array}{l}\text { Percentage of household received extra aid, remittance/commodity transfer } \\
\text { from formal or other institutions (State, NGO, UN etc) to cope up with } \\
\text { climate change }\end{array}$ & 13.3 & 33.3 & & & \\
\hline \multicolumn{6}{|l|}{ Overall effect index on household capitals } \\
\hline Lete & 0.470 & & & & \\
\hline Kunjo & 0.494 & & & & \\
\hline
\end{tabular}

When examining LEI values for different wealth groups, it is apparent that the Very Poor group is most affected and the Medium group the least (Table 3). Especially the Better Off group is experiencing outmigration and high levels of mental stress, while the poor face financial deficits and possess lower quality physical capital more prone to be damaged by the changing climate.

The LVI and LEI come to the same conclusion regarding the relative vulnerability of the two VDCs, and follows the pattern provided from key informants. Kunjo VDC is located off the main road wherefore people's options for diversifying incomes is low while Lete is located on a tourist trek and therefore having more opportunities. Both VDCs face problems with lower agricultural production, with most negative effects on the poor who have little buffer capacity. Main adaptation strategies include diversification of income generating activities, including outmigration. The vulnerability indexes arguably capture the main characteristics of the

Table 3 : Climate change effect indicator values by household capital and wealth group of Lete and Kunjo VDCs, Mustang in 2009. N $=60$.

\begin{tabular}{lcccc}
\hline \multicolumn{1}{c}{ Household capitals } & \multicolumn{3}{c}{ Effect index for different livelihood groups } \\
& Better off & Medium & Poor & Very Poor \\
\hline Human & 0.533 & 0.493 & 0.520 & 0.507 \\
Natural & 0.813 & 0.747 & 0.853 & 0.773 \\
Physical & 0.067 & 0.200 & 0.233 & 0.267 \\
Financial & 0.222 & 0.178 & 0.067 & 0.356 \\
Social & 0.267 & 0.233 & 0.300 & 0.333 \\
\hline Overall effect index & 0.475 & 0.447 & 0.478 & 0.510 \\
\hline
\end{tabular}


situation validly, and developing a comparable index for a diverse country such as Nepal could be useful to priorities where aid is most needed to ameliorate effects of climate change.

Several issues need to be discussed, however. The indexes are using weighted averages attributing equal weight to all sub-components/indicators and thereby assign a value to the importance of these. It is by no means given that the indicators of mental and/or physical distress should carry the same weight as, e.g., outmigration of skilled members. Further discussion on how to weigh different indicators is needed. Furthermore, the inclusion of sub-components and indicators is necessarily subjective but if the list is the results of a consultative process the potential bias can be reduced.

Additionally, the LVI values do not consider whether people were poor in the first place. Here the combination of wealth rank and LEI is arguably providing a more differentiated picture allowing targeting within VDCs as compared to targeting entire VDCs. The LEI could also be argued problematic, as it only reports whether a household is effected or not but does not estimate effects or losses quantitatively.

Use of indicators and indices in these approaches oversimplify a complex reality and there is no easy way to validate indices comprised of unrelated indicators. Directionality of indicators is also arguable for example higher percentage of female headed household increase or decrease communities' vulnerability to climate change impacts. In terms of data interpretation, separating the consequences of climate change from other influencing factors is difficult, if not impossible. Therefore the interpretation of LVI and LEI data must be made with care. An important influence in the study area is, e.g., the recent construction of a motorable road where previously all transportation had taken place by donkey or man power. How the effects of the new road and effects of climate change correlate, cancel out or reinforce each other is not clear. A separate issue of no less importance is the ability of respondents to assign realistic importance to the influence of various factors influencing their lives and the propensity of assigning more importance to the subject investigated by the individual researcher approaching them with questions.

\section{Conclusion}

This study applied two vulnerability assessment approaches in Kunjo and Lete VDCs of Mustang district, the LVI developed by Hahn et al. (2009) and the LEI based on the DFID (1999) livelihoods framework approach. Both indexes were assessed to validly reflect the relative differences between the two VDCs in terms of vulnerability to climate change and both could therefore usefully form the basis for a nationally applicable index. These indices could be used as a practical tool for the governments, policy makers and developmental organisations to identify vulnerable communities, understand the factors contributing to vulnerability at district or community level and also to prioritise the potential areas of intervention. Challenges prevail, however, in terms of selecting suitable indicators and assigning appropriate weights to them, in distinguishing effects of climate change from other influences, and in collecting valid data.

\section{References}

ADB. 2008. Asian Development Bank \& Nepal: Fact Sheet. Asian Development Bank, Manila. http://www.adb.org/Documents/Fact_Sheets/ NEP.pdf (accessed 30th October 2009)

Agrawala, S., Raksakulthai, V., Aalst, M., Larsen, P., Smith, J. and Reynolds, J. 2003. In Development and climate change in Nepal: focus on water resources and bydropower. Organisation for Economic Cooperation and Development, Paris, 4-8.

Brooks, N. and Adger, W.N. 2003. Country Level Risk Measures of Climate-Related Natural Disasters and Implications for Adaptation to Climate Change. Tyndall Centre Working Paper 26: http://www.tyndall.ac.uk/publications / working_papers/wp26.pdf (Accessed on 10-102008)

Chalise, S.R. and Khanal, N.R. 2001. An introduction to climate, hydrology and landslide hazards in the Hindu Kush-Himalayan region. In Landslide Hazard Mitigation in the Hindu Kush-Himalayas, (eds.) Tianchi, L., Chalise, S.R., Upreti, B.N., Kathmandu: ICIMOD, 51-62.

Chapagain, BK., Subedi, R. Paudel, N.S. 2009. Exploring local knowledge of climate change: some reflections. Forest and Livelihood 8 (1): 106110. 
Christensen, M., Rayamajhi, S. and Meilby, H. 2009. Balancing fuelwood and biodiversity concerns in rural Nepal. Ecol Modell 220: 522-532.

Department of Hydrology and Meteorology, 2008. Climatological Records of Nepal. Kathmandu, Nepal.

DFID. 1999. Sustainable livelihood guidence sheet. Department for international development, London, UK http:// training.itcilo.it/decentwork/staffconf2002/ presentations /SLA $\% 20$ Guidance $\% 20$ notes $\%$ 20Section\%202.pdf (Accessed on 10-10-2008),

Dahal, N. 2006. "Implications of climate change on biodiversity in Nepal: some observations and opportunities", paper presented at 23rd Warden Seminar November 2006 held in Pokhara, Nepal http:/ / www.mtnforum.org/oldocs/626.pdf (Accessed on 10-10-2008)

Ebi, K., Kovats, R.S. and Menne, B. 2006. An approach for assessing human health vulnerability and public health interventions to adapt to climate change. Environmental Health Perspectives 114: 1930 1934.

Eriksen, S. and Kelly, P.M. 2006. Developing credible vulnerability indicators for policy assessment. Mitigation and Adaptation Strategies for Global Change, Mitigation and Adaptation Strategies for Global Change, 12 (4): 495-524

Hahn, M.B., Riederer, A.M. and Foster, S.O. 2009. The Livelihood Vulnerability Index: A pragmatic approach to assessing risks from climate variability and change-a case study in Mozambique. Global Environmental Change (19): 74-88 available on http://www.sage.wisc.edu/pubs/articles/F-L/ Hahn/hahn2009GEC.pdf (Accessed on 10-102008)

ICIMOD. 2007. Flash Flood Hotspot Mapping in the Hindu Kush-Himalayan Region (draft DVD ROM). Kathmandu: International Centre for Integrated Mountain Development ICIMOD

IISD. 2003. [online] "Livelihoods and Climate change, Combining disaster risk reduction, natural resource management and climate change adaptation in a new approach to the reduction of vulnerability and poverty", A Conceptual Framework Paper Prepared by the Task Force on Climate Change, Vulnerable Communities and Adaptation, The International Institute for
Sustainable Development, Manitoba, Canada, http://data.iucn.org/dbtw-wpd/edocs/2003034.pdf (Accessed on 7-10-2008)

IPCC. 2001. Climate change 2001: Impacts, Adaptation and Vulnerability. Intergovernmental panel on climate change, 2001

IPCC. 2007. Summary for Policymakers, In Climate change 2007: impacts, adaptation and vulnerability. (eds.) Parry, M.L., Canziani, O.F., Palutikof, J.P., Linden, P.J., and Hanson, C.E. Contribution of Working Group II to the Fourth Assessment Report of the Intergovernmental Panel on Climate Change, Cambridge, Cambridge University Press: 1000p

Kasperson, J.X., Kasperson, R.E. and Turner, B.L. 1996. Regions at Risk: Comparisons of Threatened Environments. United Nations University Press, New York.

Lohani, S.N. 2007. Climate change in Nepal: Shall we wait until bitter consequences?. Agriculture and Environment. 8: 38-45.

MoEST and UNDP. 2008. National Adaptation Programme of Action to Climate Change. Ministry of Environment, Science and Technology, Government of Nepal and United Nations Development Programme. Kathmandu.

NPC. 2001. Population Census 2001. National Planning Commission, Central Bureau of Statistics, His Majesty's Government/Nepal. Kathmandu, Nepal.

Oxfam. 2009. Even the Himalayas have stopped Smiling - Climate Change, Poverty and Adaptation in Nepal. Oxfam International, Lalitpur.

Pokharel, B.K. and Byrne, S. 2009. Climate Change Mitigation and Adaptation Strategies in Nepal's Forest Sector: How can Rural Communities Benefit? NSCFP Discussion Paper 7. Nepal Swiss Community Forestry Project, Kathmandu.

Razafindrabe B.H.N. 2007. Understanding Livelihood Security and Climate Change Adaptation: A Case Study of Environment, Disasters, and Human Security in East Central Madagascar. International Environment and Disaster Management Laboratory, Graduate School of Global Environmental Studies, Kyoto University, http:/ 
/ ww w.i ed m.ges.kyoto-u.ac.jp/ Bam_ResearchMethod_IEDM.pdf (Accessed on 7-10-2008)

Regmi, B.R., Suwal, R., Shrestha, G., Sharma, G.B., Thapa, L. and Manandhar, S. 2009. Community resilience in Nepal. Tiempo - Climate and Development 73: 7-10.

Selvaraju, R., Subbiah, A.R., Baas, S. and Juergens, I. 2006. Livelihood adaptation to climate variability and change in drought-prone areas of Bangladesh. Developing institutions and options, FAO, Rome.

Shakya, N.M. 2003. Hydrological Changes Assessment and Its Impact on Hydro Power Projects of Nepal, In Climate change impacts and adaptation options in Nepal's bydropower sector with a focus on hydrological regime changes including GLOF,
Department of Hydrology and Meteorology and Asian Disaster Preparedness Center, 5-6 March 2003, Kathmandu.

Shrestha, A.B., Wake, C.P., Mayewski,P.A. and Dibb, J.E. 1999. Maximum Temperature Trends in the Himalaya and its Vicinity; An Analysis Based on Temperature Records from Nepal for the Period 1971 - 94, Climate 12: 2775-2789.

Smit, B., Pilifosova, O., Burton, I., Challenger, B., Huq, S., Klein, R.J.T. and Yohe, G. 2007. Adaptation to climate change in the context of sustainable development and equity. In Climate change 2007: impacts, adaptation and vulnerability (eds.) Parry, M., Canziani, O., Palutikof, J., Linden, P. and Hanson, C. Contribution of Working Group II to the Fourth Assessment Report of the Intergovernmental Panel on Climate Change, Geneva. 876-912. 